\title{
O ESPORTE E O LAZER NA ESTRUTURA ORGANIZACIONAL DA ADMINISTRAÇÃO PÚBLICA MUNICIPAL
}

Recebido em: 04/02/2016

Aceito em: 01/07/2016

Filipe Fuhrmann Mertins, Mauro Myskiw

Universidade Federal do Rio Grande do Sul Porto Alegre - RS - Brasil

Gustavo Roese Sanfelice Universidade FEEVALE Novo Hamburgo - RS - Brasil

RESUMO: Este trabalho se situa nos debates sobre a reforma administrativa na gestão pública verificada a partir da promulgação da Constituição de 1988, com destaque sobre a maior autonomia e responsabilidade dos municípios no sistema de proteção social brasileiro. A municipalização também é uma questão relevante na garantia do esporte e do lazer como direitos sociais dos cidadãos brasileiros e, por isso, no presente estudo analisamos as configurações organizacionais materializadas nos esforços administrativos dos cinco municípios mais populosos do Rio Grande do Sul (Porto Alegre, Caxias do Sul, Pelotas, Canoas e Santa Maria). O estudo teve um delineamento qualitativo na medida em que buscou analisar os significados das configurações organizacionais no campo da gestão pública. As informações analisadas foram produzidas a partir de entrevistas semiestruturadas com dez gestores municipais das pastas de esporte e lazer, como também do levantamento de documentos, sobretudo leis e decretos. Os resultados de investigação apontam para uma configuração organizacional híbrida, compreendendo esforços orientados para a existência de um aparato burocrático de intervenção direta com arenas de participação pública, mas também uma engenharia organizacional flexível de captação e de repasses de recursos, tanto no sentido de escapar da burocracia, como de ampliação da capacidade de atuação.

PALAVRAS CHAVE: Esportes. Atividades de Lazer. Organizações. Administração Pública.

\section{SPORT AND LEISURE IN THE ORGANIZATIONAL STRUCTURE OF THE MUNICIPAL PUBLIC ADMINISTRATION}

ABSTRACT: This work is part of the debate on administrative reform in public administration that has occurred since the enactment of Brazil's 1988 Constitution, with emphasis on municipalities' greater autonomy and responsibility within the social protection system. Municipalization is also a relevant issue in ensuring sport and leisure and social rights for Brazilian citizens. Therefore, this study looks into the organizational configurations materialized in the administrative efforts of the five most populous municipalities of the state of Rio Grande do Sul (Porto Alegre, Caxias do Sul, Pelotas, Canoas, and Santa Maria). The study was qualitative in that it sought to analyze the meanings of organizational 
configurations in the field of public administration. Information analyzed was produced by semi-structured interviews with ten managers of municipal departments of sports and leisure, as well through document survey, especially laws and decrees. Results point to a hybrid organizational configuration comprising efforts oriented to the existence of a bureaucratic apparatus for direct intervention in public participation arenas, but also to a flexible organizational engineering for raising and transferring funds, in order both to escape bureaucracy and expand capacity for action.

KEYWORDS: Sports. Leisure Activities. Organizations. Public administration.

\section{Introdução}

Este trabalho se localiza no campo de discussões em torno da administração pública, especificamente no que diz respeito à estruturação de organizações que materializam a gestão de políticas públicas de esporte e de lazer em grandes municípios do estado do Rio Grande do Sul. Ele resulta do recorte de uma dissertação de mestrado defendida no Programa de PósGraduação em Inclusão Social e Acessibilidade da Universidade Feevale, esta desenvolvida com enfoque na organização e na estruturação das Políticas Públicas de Esporte e Lazer.

O ponto de partida das reflexões que propomos neste texto é a institucionalização do esporte e do lazer como direitos sociais na Constituição Federal Brasileira, nos seus artigos $6^{\circ}$ e $217^{\circ}$ (BRASIL, 1988). Também partimos do pressuposto de que, após a promulgação dessa Carta Magna com as suas reformas políticas e tributárias, desde o início da década de 1990, já se observava um redesenho da estrutura organizacional do sistema de proteção social brasileiro, em diferentes áreas (educação, saúde, assistência social, habitação, etc.), isto em direção a um processo de descentralização. Nesse processo, no interior do Estado federativo brasileiro, os estados e os municípios passaram a ser, de fato, politicamente autônomos ${ }^{1}$.

Uma vez que os municípios brasileiros - pessoas jurídicas de direito público - foram declarados entes federativos autônomos e que se nota um movimento de municipalização na gestão (ARRETCHE, 1999), lhes cabe desenvolver um aparato administrativo-burocrático

\footnotetext{
${ }^{1}$ Um exame crítico mais detalhado dos fatores que determinaram a descentralização das políticas sociais no Brasil está presente no trabalho de Marta Arretche (1999).
} 
para a proteção social dos brasileiros nos locais de sua moradia. Diante disso, a questão que orientou a investigação se refere a como municípios estão se estruturando do ponto de vista organizacional para que os direitos sociais sejam garantidos. Especificamente, para os interesses deste estudo, que tipos de configurações organizacionais foram sendo constituídas para que o esporte e o lazer fossem vivenciados enquanto direitos sociais?

Já não é recente o maior enfoque sobre a municipalização das ações do Estado na garantia do esporte e do lazer como direitos sociais do cidadão brasileiro. Essa questão tornou-se ainda mais central em 2006, por ocasião da realização da II Conferência Nacional do Esporte, constituída por 326 conferências (regionais/municipais, estaduais e a nacional). Um dos objetivos de destaque dessas conferências era a formulação de um novo Sistema Nacional de Esporte e Lazer (SNEL), sendo que após o conjunto de discussões e deliberações o documento final enfatiza o papel da municipalização como arena-chave na garantia dos referidos direitos sociais (BRASIL, 2006).

Ademais, vale destacar aqui que, no contexto das discussões sobre a municipalidade das políticas públicas de esporte e lazer, existem muitos trabalhos e/ou reflexões, como o de Stigger (1992), sobre a administração dos parques públicos do município de Porto Alegre; de Castellani Filho (2006, 2007), a respeito da elaboração, a implantação e a avaliação das políticas de lazer nos municípios; de Linhales et al. (2008), sobre as representações construídas pelos gestores do esporte e do lazer no âmbito de 13 municípios de Minas Gerais; de Amaral e Kikuchi (2011), atento para o aumento dos espaços destinados ao lazer na cidade de Suzano, São Paulo; de Rodrigues e Marcellino (2011), sobre a inclusão do lazer enquanto área da política pública de Porto Alegre; de Amaral e Costa (2012), em relação às possibilidades de matricialidade na administração pública do lazer em municípios do interior do estado de São Paulo; de Sawitzki (2012), sobre os gestores e as suas propostas políticas para as áreas de esporte e de lazer no noroeste do estado do Rio Grande do Sul; de Silva et al. 
(2012), relativo ao planejamento da gestão pública e das ações intersetoriais em esporte, lazer, cultura e turismo no município de Ilhéus; e de Menezes; Oliveira e Souza (2012), em relação aos discursos dos gestores municipais sobre a política esportiva da região metropolitana do Recife.

Estes trabalhos não esgotam as discussões, mas mostram que há um debate sobre a questão da municipalização das políticas públicas de esporte e de lazer. No decorrer deste texto procuraremos contribuir um pouco com as discussões, sendo nosso objetivo apresentar análises sobre as configurações organizacionais materializadas nos esforços administrativos dos cinco municípios mais populosos do Rio Grande do Sul, entre os anos de 2009 e 2012, para dar conta das questões que envolvem os direitos sociais ao esporte e ao lazer. Para tanto, foram estudadas as configurações organizacionais de Porto Alegre, Caxias do Sul, Pelotas, Canoas e Santa Maria, com enfoque sobre aquelas instituídas e vigentes, trazendo uma análise da estrutura administrativa, o que não significa que ignoramos a existência de dimensões políticas (de governabilidade).

\section{Decisões Metodológicas}

Com a finalidade de analisar as configurações organizacionais materializadas nos esforços administrativos dos municípios do Rio Grande do Sul, isso entre 2009 e 2012, no que tange ao esporte e ao lazer, desenvolvemos uma investigação qualitativa, no sentido da compreensão dos significados da estrutura organizacional constituída nos esforços administrativos do esporte e do lazer, tendo em vista o entendimento do que elas representam no contexto da gestão pública nas municipalidades estudadas. 
Tomando como referência a busca dos municípios mais populosos do estado, e tendo como base os dados do Instituto Brasileiro de Geografia e Estatística (IBGE) ${ }^{2}$, foram selecionados os municípios de Porto Alegre (1.409.351 pessoas), Caxias do Sul (435.564 pessoas), Pelotas (328.275 pessoas), Canoas (323.827 pessoas) e Santa Maria (261.031 pessoas). Entre os meses de setembro e dezembro de 2012, buscamos informações sobre os gestores do esporte e do lazer nesses municípios, com o intuito de realizar entrevistas com aqueles que tivessem vínculos mais estreitos e conhecimentos profundos acerca das configurações organizacionais. Entramos em contato com os gestores identificados e apresentamos um primeiro conjunto de informações sobre a pesquisa (contextualização, relevância, propósitos e procedimentos). Àqueles interlocutores que se disponibilizaram a participar do estudo, foram encaminhados uma Carta de Apresentação do Pesquisador, Termo de Consentimento de Direito de Imagem da Instituição, Termo de Consentimento Livre e Esclarecido e roteiro da entrevista. Após o recebimento desses materiais, os gestores poderiam aceitar ou declinar a participação, todavia, membros dos cinco municípios manifestaram interesse e disponibilidade.

Assim, após assinados os referidos termos, foram realizadas dez entrevistas com gestores do esporte e do lazer dos municípios mais populosos do estado, conforme descrito no Quadro 1. Nos casos em que os principais responsáveis pela gestão não pudessem participar, estes indicaram outras pessoas que tinham relação e experiência direta com o tema. As questões das entrevistas foram orientadas pelos seguintes eixos temáticos: descrição da organização e estrutura de formulação e gestão das políticas públicas de esporte e de lazer; descrição detalhada das ações programáticas nas áreas de esporte e de lazer; indicações de documentos de institucionalização e normatização da estrutura organizacional, assim como das ações programáticas.

\footnotetext{
${ }^{2}$ Dados do Censo Demográfico realizado em 2010, pelo Instituto Brasileiro de Geografia e Estatística (IBGE), disponível em: http://www.cidades.ibge.gov.br/xtras/uf.php?lang=\&coduf=43\&search=rio-grande-do-sul Acesso em: 12 ago. 2012.
} 
Quadro 1-Descrição dos gestores municipais de esporte e de lazer entrevistados.

\begin{tabular}{|l|c|}
\hline Vínculos dos entrevistados & Identificação \\
\hline \multirow{2}{*}{ Secretário/Superintendente Municipal de Esporte e Lazer } & Gestor 01 \\
\cline { 2 - 2 } & Gestor 02 \\
\cline { 2 - 2 } $\begin{array}{l}\text { Professores da Rede Municipal de Ensino, cedidos para a pasta responsável pelo esporte e } 03 \\
\text { lazer }\end{array}$ & Gestor 04 \\
\cline { 2 - 2 } & Gestor 05 \\
\cline { 2 - 2 } Professores/técnicos da pasta específica de esporte e de lazer do município 06 \\
\hline Agente Administrativo da Secretaria de Saúde, cedido para a pasta responsável pelo esporte e & Gestor 07 \\
\cline { 2 - 2 } lazer & Gestor 08 \\
\hline
\end{tabular}

Fonte: elaboração dos autores

O conteúdo das entrevistas com os gestores municipais foi registrado em áudio e, depois, transcrito, passando a compor o rol de informações a serem analisadas. Além desses dados das entrevistas, também foram feitos levantamentos e buscas de documentos citados pelos interlocutores ou de outros que se mostravam importantes no desenvolvimento da investigação, com destaque para as legislações (leis e decretos municipais).

O processo de análise das informações das entrevistas realizadas, assim como dos documentos, esteve orientado para a descrição das configurações organizacionais que compreendiam os esforços administrativos relacionados ao esporte e ao lazer, tendo em vista a compreensão dos seus significados no campo da gestão pública municipal. Esse processo seguiu as orientações de Flick (2007) acerca das categorizações temática e global, contemplando: a identificação de distintos modos de configurações organizacionais relatados pelos gestores entrevistados; o desenvolvimento de um esquema ilustrativo dos esforços administrativos materializados pelos municípios; a descrição, ainda que sucinta, de situações que caracterizavam e exemplificavam os modos de organização; a interpretação sobre o que representam as configurações no contexto da gestão pública municipal.

$\mathrm{Na}$ operacionalização da análise, vale ressaltar, não procuramos desenvolver uma comparação das configurações organizacionais dos distintos municípios, mas destacar uma 
análise sobre a constituição da administração pública das maiores municipalidades do estado do Rio Grande do Sul.

\section{Configurações das Estruturas Administrativas}

Não vamos trazer aqui uma retomada das questões que atravessam a gestão pública, mas, para que as informações a seguir sejam compreensíveis, nos cabe uma breve síntese daquilo que designamos de configurações administrativas. Uma primeira configuração é a que tradicionalmente tem se chamado de 'administração burocrática', emergente da necessidade de instituição da dissociação entre o poder público (em torno do qual gira o interesse comum) e o poder privado (em torno do qual gira o interesse particular). No caso do poder público essa configuração supõe a constituição de uma estrutura racional, normativa e impessoal que assume o monopólio sobre o conjunto de bens considerados coletivos, estes frequentemente garantidos como direitos sociais. Nesse sentido, a existência de uma configuração burocrática, no âmbito da administração pública, está relacionada a formas de dominação ${ }^{3}$ e de poder ${ }^{4}$ relativas a questões sociais (como a segurança, a saúde, a educação, o esporte, o lazer, etc.) e à intervenção do Estado.

No campo da gestão pública é bastante recorrente a apresentação dos limites da 'administração burocrática' (ineficiente, custosa, lenta, tutorial), sobretudo diante de crises fiscais, de empoderamento das grandes corporações multinacionais e dos fluxos internacionais de capitais financeiros. Questões como essas estão relacionadas com reformas administrativas e com a emergência de outra configuração, conhecida como 'gerencialismo', a qual, dentre outras características, envolve diminuições do tamanho do aparato burocrático estatal em face

\footnotetext{
3 O trabalho de Max Weber intitulado "Economia e Sociedade" (WEBER, 2009) traz elementos históricos e teóricos muito relevantes para a compreensão dessa característica.

${ }^{4}$ Essa reflexão está teoricamente desenvolvida no trabalho de Pierre Bourdieu (2005).
} 
da sua atuação por meio de financiamento e regulação ${ }^{5}$. A reforma administrativa da configuração gerencialista, fortemente impactada pela profissionalização da gestão e uma preocupação com a eficiência e eficácia operacional, compreende a criação de agências executivas descentralizadas ou o estabelecimento das parcerias e convênios com organizações sem fins lucrativos ou mesmo com a iniciativa privada, num sentido de ampliação flexível do aparato estatal.

Contudo, essa configuração gerencialista implementa a formação de uma elite tecnocrática no âmbito da gestão pública, assim como um maior empoderamento das instâncias executivas, acarretando a carência de disposição dos discursos sociopolíticos nas decisões, estruturas e práticas da administração ${ }^{6}$. É frente a questões como essas que Paula (2005) observa, nas experiências brasileiras das décadas de 1980 e 1990, o surgimento de outra vertente (ou configuração) administrativa voltada para o resgate da participação política, especialmente da participação popular, que a autora denominou de 'societal', cujas práticas valorizam, dentre outros aspectos e práticas, a (re) aproximação da sociedade civil na gestão pública, alimentando uma concepção participativa e não apenas profissional (tecnocrata), esta relacionada com a instituição de mais arenas públicas de participação e também com uma formação sociopolítica dos gestores.

Essas configurações administrativas (burocrática, gerencialista e societal), embora muito sucintamente demarcadas neste texto, são bases muito importantes na compreensão da gestão pública. Orientados por isso que passamos a descrever as informações e análises, assim como produzir algumas interpretações sobre a administração do esporte e do lazer no âmbito das municipalidades.

\footnotetext{
${ }^{5}$ Um dos autores-gestores que tratou de mostrar a relevância dessa transposição entre a gestão burocrática e a gerencial foi Luiz Carlos Bresser-Pereira (BRESSER-PEREIRA, 1996, 2000). Ao abordar a reforma administrativa do Governo Federal brasileiro, por ele coordenada em 1995, aponta os limites da administração burocrática e a necessidade de um Estado Gerencial.

${ }^{6}$ Essa posição crítica é apresentada por Paula (2005) na obra "Por uma nova gestão pública: limites e potencialidades da experiência contemporânea", quando ela expõe os limites da nova administração (gerencial) que, ao se aproximar das dinâmicas do mercado ou dos setores privados (neopatrimonialismo?), acaba gerando uma série de distorções.
} 


\section{Estrutura Administrativa Direta de Intervenção}

A primeira análise que apresentamos trata dos esforços municipais de instituição de uma estrutura burocrática própria, estes capazes de sublinhar o lugar do esporte e do lazer enquanto questões sociais relevantes, dignas de alguma autonomia para manusear um conjunto de recursos públicos em face de uma intervenção direta. Considerando os conteúdos das entrevistas, desenvolvemos a Figura 1 para representar a instituição de tais esforços.

Figura 1 - Esforços dos municípios na instituição de estruturas burocrático-administrativas para a garantia do direito de esporte e de lazer.

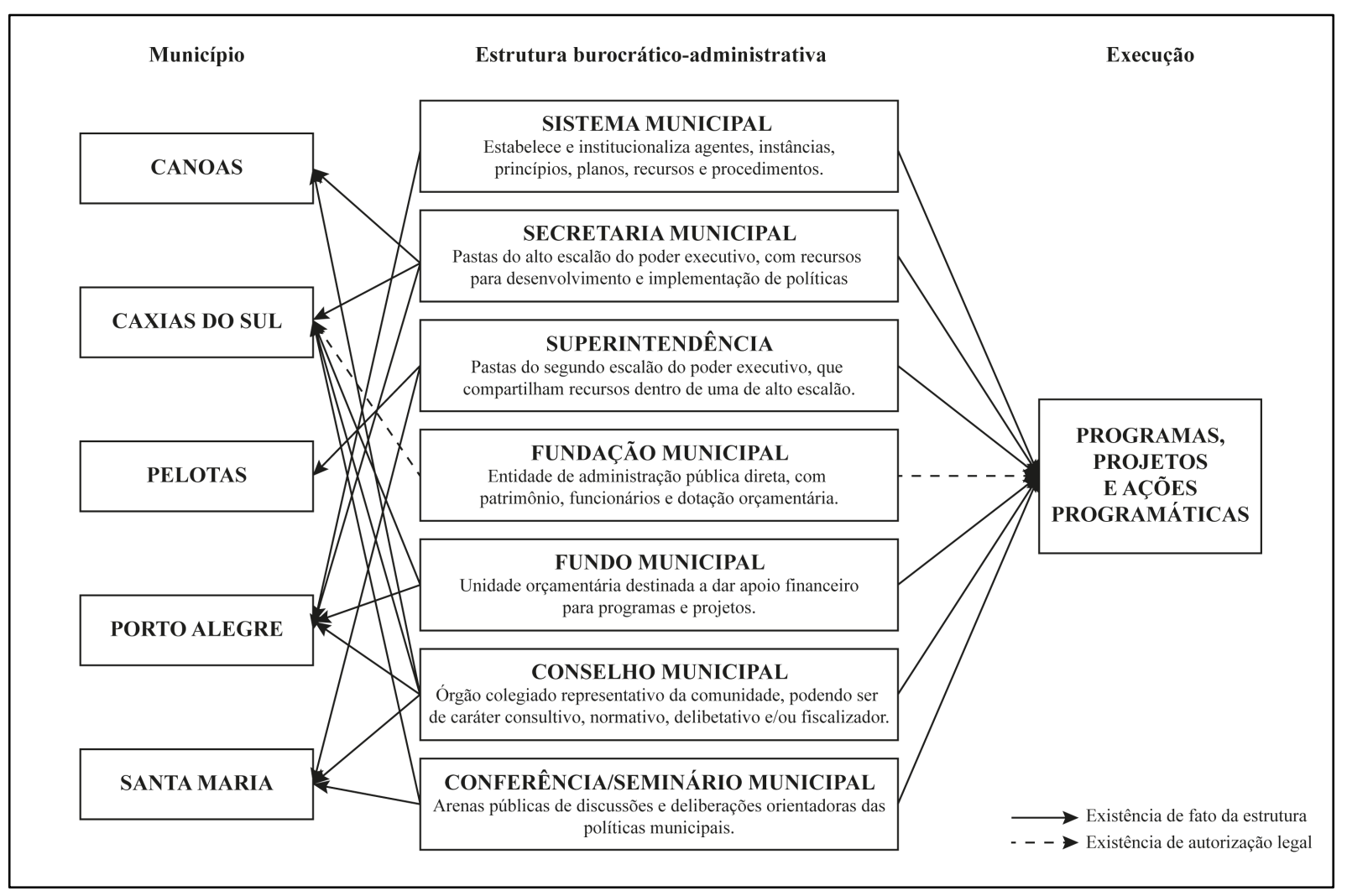

Fonte: elaboração dos autores

O 'ápice' dessa instituição, nos argumentos de nossos interlocutores, estava representado na implementação de um Sistema Municipal que estabelecesse os envolvidos (pessoas físicas ou jurídicas, entidades públicas, privadas ou do terceiro setor), as instâncias (conselhos, secretarias, comissões, fundos, etc.), os princípios norteadores, os planos, as políticas públicas/sociais, os objetivos estratégicos, a definição das fontes de recursos (sobretudo os fixos), as competências, os direitos e deveres, como também as dinâmicas de 
processos internos. No caso dos municípios estudados, apenas os dirigentes de Porto Alegre e de Caxias do Sul indicaram a existência de uma estrutura de esporte e de lazer nesse sentido. No caso de Porto Alegre, essa instituição envolveu a promulgação da Lei Complementar $340 / 1995^{7}$

Constituir e instituir legalmente um Sistema Municipal executivo significava materializar, de uma maneira bastante forte, as questões do esporte e do lazer no cotidiano da municipalidade, uma vez que colocava em ação um conjunto de agentes e de instituições dedicados a elas. Contudo, embora esse esforço fosse apontado como desejável ('o ápice’), o que observamos era uma busca (num sentido de luta, de disputa) para garantir, pelo menos, alguma estrutura burocrática particular no âmbito da administração pública municipal. Afirmamos isso porque identificamos um tom de contentamento e de orgulho daqueles dirigentes que mencionavam a criação das secretarias municipais relacionadas, especificamente, ao esporte e ao lazer enquanto pastas do alto escalão do poder executivo, localizando esses dois direitos sociais dentre aqueles que contavam com recursos públicos (funcionários, infraestrutura, dotação orçamentária) para desenvolver e implementar políticas nessas áreas.

Dentre os municípios estudados, aqueles que contavam com essa estrutura eram: Porto Alegre, com a Secretaria Municipal de Esportes, Recreação e Lazer (SME), criada pela Lei 7330/1993 ${ }^{8}$; Caxias do Sul, com a Secretaria Municipal de Esporte e Lazer (SMEL), criada

\footnotetext{
${ }^{7}$ PORTO ALEGRE. Lei Complementar $\mathbf{n}^{\circ}$ 340, de 12 de janeiro de 1995. Institui o Sistema Municipal do Desporto e dá outras providências. Disponível el http://www2.portoalegre.rs.gov.br/sme/default.php?reg=5\&p secao=99 . Acesso em: 29 dez. 2012.

8 PORTO ALEGRE. Lei n $^{\circ}$ 7330, de 05 de outubro de 1993. Cria a Secretaria Municipal de Esportes, Recreação e Lazer - SME, e dá outras providências. Disponível em: http://www2.portoalegre.rs.gov.br/netahtml/sirel/avancada.html . Acesso em: 28 dez. 2012. 
pela Lei $6076 / 2003^{9}$, esta alterada pela Lei complementar $321 / 2008^{10}$; e Canoas, com a Secretaria Municipal de Esporte e Lazer (SMEL), criada pela Lei 5363/2009 ${ }^{11}$.

Contudo, vale ressaltar que o tom de contentamento - por contar com pastas específicas - se misturava com o descontentamento no que diz respeito às prioridades e ao volume dos recursos, principalmente os financeiros. É nesse sentido que o secretário da pasta de um dos municípios ${ }^{12}$ (GESTOR 02) relatou o crescimento da demanda, mas sem prioridades, mencionando a necessidade de construção de um grande ginásio esportivo e o fato de nunca restarem recursos, devido a outros investimentos considerados prioritários. Nessa linha de raciocínio é que também os dirigentes de Porto Alegre comentaram sobre a realidade de que apenas $0,3 \%$ do orçamento anual do município era destinado à Secretaria específica, valor flagrantemente insuficiente para todas as demandas do Sistema Municipal.

Diferente de Porto Alegre, Caxias e Canoas, no caso dos municípios de Pelotas e Santa Maria, a mobilização dos recursos públicos para a materialização de políticas públicas/sociais nas áreas de esporte e de lazer não envolvia tamanha especificidade nos órgãos de alto escalão do executivo. Isso porque o esporte e o lazer estavam localizados em secretarias que compartilhavam outras questões sociais. Em Pelotas, a Lei 5763/2010 estabeleceu, como órgão de assessoramento diretamente vinculado ao gabinete do prefeito, a Secretaria Municipal de Educação e Desporto, cabendo a uma Superintendência subordinada de

\footnotetext{
${ }^{9}$ CAXIAS DO SUL. Lei ${ }^{\circ} \mathbf{6 . 0 7 6}$, de 10 de setembro de 2003. Cria a Secretaria Municipal de Esporte e Lazer e dá outras providências. Disponível em: http://portal.tce.rs.gov.br/aplicprod/f?p=50202:4:263159601882518::NO::P4_CD_LEGISLACAO:190167 Acesso em: 28 dez. 2012.

${ }^{10}$ CAXIAS DO SUL. Lei complementar $\mathbf{n}^{\circ}$ 321, de 22 de dezembro de 2008. Dispõe sobre a estrutura administrativa e o funcionamento do Poder Executivo Municipal de Caxias do Sul. Disponível em: http://hamurabi.camaracaxias.rs.gov.br/Hamurabi-faces/externo/exibicao.jsf?leiId=1322\&from=resultados Acesso em: 28 dez. 2012.

${ }^{11}$ CANOAS. Lei $\mathbf{n}^{\mathbf{0}} \mathbf{5 . 3 6 3}$, de 02 de janeiro de 2009. Dispõe sobre a estrutura, organização e funcionamento do poder executivo municipal de Canoas e dá outras providências. Disponível em: http://c-mara-municipal-decanoas.jusbrasil.com.br/legislacao/311168/lei-5363-09 . Acesso em: 27 dez. 2012.

${ }^{12}$ Para garantir o sigilo da identidade dos interlocutores, optamos por nos referirmos dessa forma - "de um dos municípios" quando a informação utilizada foi apresentada por um dos gestores entrevistados. Nesses casos, identificaremos o gestor pela numeração disponível no Quadro 1 (seção das decisões metodológicas). Adotaremos esse mesmo procedimento para as situações semelhantes posteriores.
} 
Desporto e Lazer tratar das demandas dessa área ${ }^{13}$. No caso desse município, os gestores entrevistados afirmaram que não se pretende criar uma pasta exclusiva, pois atualmente existe uma grande quantidade de secretarias e autarquias no município. Já em Santa Maria, através da Lei 5189/2009, foi estabelecida uma Secretaria de Juventude, Esporte, Lazer, Idoso e Criança, esta integrada por três diferentes superintendências, dentre elas a de Esportes e Lazer $^{14}$, o que sustenta um discurso pessimista, no sentido de que os recursos destinados à Secretaria - estes já escassos - serão disputados e distribuídos entre as diferentes questões e projetos.

Além dessas unidades burocráticas (de primeiro e de segundo escalão), foram mencionadas as Fundações de Esporte e Lazer vinculadas às secretarias, como organizações alternativas capazes de garantir maior efetividade no aparato administrativo público. Essas Fundações são entidades de administração pública direta, isto é, pessoas jurídicas de direito público, criadas por lei, pelo próprio poder público para garantir os direitos sociais, com seus próprios patrimônios, funcionários e dotação orçamentária fixa. Nenhum dos municípios estudados contava com Fundações de Esporte e de Lazer ativas, mas, a respeito disso, o secretário de um dos municípios (GESTOR 01) apontou a “vontade da administração", para a próxima gestão, de elaborar a lei para a criação de uma Fundação de Esporte e Lazer para atuar junto à Secretaria. Também o gestor do município de Caxias do Sul mencionou a existência de uma autorização legal para a criação da Fundação de Esporte e Lazer, desde 1996, mas que ainda há uma discussão interna sobre como atender a demanda crescente de recursos para a Secretaria. Outra informação nesse sentido foi a experiência da Fundação de

\footnotetext{
${ }^{13}$ PELOTAS. Lei $\mathbf{n}^{\circ} \mathbf{5 . 7 6 3}$, de 23 de dezembro de 2010. Dispõe sobre a Reforma Administrativa do Poder Executivo do Município de Pelotas, consolida a Legislação acerca dos Cargos em Comissão e das Funções Gratificadas. Disponível em: <http://externo.pelotas.com.br:51000/transparencia/leis-edecretos/leis.php?secao=lista-LEIS.htm?tipo_site=1 >. Acesso em: 29 dez. 2012.

14 SANTA MARIA. Lei $\mathbf{n}^{\mathbf{0}} \mathbf{5 . 1 8 9}$, de 30 de abril de 2009. Dispõe sobre a estrutura, organização e funcionamento do poder executivo municipal, altera a Lei 4821, de 18 de janeiro de 2005, e dá outras providências. Disponível em: http://www.leismunicipais.com.br/legislacao-municipal-da-prefeitura/4210/leis-desanta-maria.html . Acesso em: 30 dez. 2012.
} 
Cultura, Esporte, Lazer e Turismo de Pelotas, criada pela Lei municipal 3484/1992, atuante até 2006 na área do esporte e do lazer ${ }^{15}$.

Juntamente com as Fundações, a conquista do aparato burocrático de administração do esporte e do lazer foi mencionada em relação à criação dos Fundos Municipais, numa lógica de garantia de recursos financeiros específicos, estes definidos e instituídos legalmente, incluindo repasses de outras esferas de governos e/ou dotações orçamentárias próprias. Um dos exemplos desse aparato foi o Fundo Municipal do Desenvolvimento do Esporte e do Lazer (FUNDEL) do Município de Caxias do Sul, criado em 2003 pela Lei 6160/2003 ${ }^{16}$, reformulado pela Lei $7207 / 2010^{17}$, como uma unidade orçamentária da Secretaria Municipal de Esporte e Lazer, destinado a dar apoio financeiro a programas e projetos de caráter de esporte e lazer. Também verificamos a existência de um Fundo Municipal no Município de Porto Alegre, Fundo Municipal de Desenvolvimento Desportivo (FUNDESP), criado pela Lei Complementar $340 / 1995^{18}$, regulamentado pelo Decreto $11481 / 1996^{19}$, como unidade orçamentária para dar apoio financeiro a programas e projetos de caráter esportivo.

Num sentido de garantir a participação da população, especificamente dos representantes das entidades vinculadas ao esporte e ao lazer, foram citados, como estruturas administrativas, os Conselhos Municipais. Dos municípios estudados, Canoas, através da Lei

\footnotetext{
${ }^{15}$ PELOTAS. Lei $\mathbf{n}^{\mathbf{0}} \mathbf{3 . 4 8 4}$, de 12 de fevereiro de 1992. Dispõe sobre a Fundação de Cultura, Esporte, Lazer e Turismo de Pelotas e dá outras providências. Disponível em: https://www.leismunicipais.com.br/a/rs/p/pelotas/lei-ordinaria/1992/348/3484/lei-ordinaria-n-3484-1992-dispoesobre-a-fundacao-de-cultura-esporte-lazer-e-turismo-de-pelotas-e-da-outras-providencias.html . Acesso em: 30 dez. 2012.

${ }^{16}$ CAXIAS DO SUL. Lei $\mathbf{n}^{\mathbf{0}} \mathbf{6 . 1 6 0}$, de 17 de novembro de 2003. Cria o Fundo Municipal de Desenvolvimento do Esporte e Lazer de Caxias do Sul (FUNDEL) e o Fundo Especial de Esportes do Município (FEES). Disponível em: http://www.camaracaxias.rs.gov.br/Leis/LO/LO-06160.pdf . Acesso em: 06 jan. 2013.

17 CAXIAS DO SUL. Lei $\mathbf{n}^{\mathbf{0}} \mathbf{7 . 2 0 7}$, de 10 de novembro de 2010. Reformula o Fundo Municipal de Desenvolvimento do Esporte e Lazer de Caxias do Sul (FUNDEL) e do Fundo Especial de Esportes do Município (FEES). Disponível em: http://www.camaracaxias.rs.gov.br/Leis/LO/LO-07207.pdf . Acesso em: 06 jan. 2013.

${ }^{18}$ PORTO ALEGRE. Lei Complementar no 340, de 12 de janeiro de 1995. Institui o Sistema Municipal do Desporto e dá outras providências. Disponível em: http://www2.portoalegre.rs.gov.br/sme/default.php?reg=5\&p_secao=99 . Acesso em: 29 dez. 2012.

${ }^{19}$ PORTO ALEGRE. Decreto $\mathbf{N}^{\mathbf{0}}$ 11.481, de 15 de abril de 1996. Regulamenta a Lei Complementar $n^{\circ} 340$, de 12 de janeiro de 1995, que institui o Sistema Municipal de Desporto. Disponível em: http://www2.portoalegre.rs.gov.br/sme/default.php?reg=6\&p_secao=99 . Acesso em: 29 dez. 2012.
} 
4682/2002, instituiu o Conselho Municipal do Esporte e do Lazer $^{20}$; Caxias do Sul, através da Lei 5089/1999, criou o Conselho Municipal do Desporto ${ }^{21}$; Porto Alegre, através da Lei Complementar 340/1995, criou o Conselho Municipal do Desporto, este regulamentado pelo Decreto 15126/2006 22 ; e Santa Maria criou o Conselho Municipal de Esporte e Lazer a partir da Lei n $1213 / 1965^{23}$, modificando sua estrutura com base no disposto na Lei 4609/2002 ${ }^{24}$. As configurações, assim como as finalidades dos Conselhos referidos acima guardam peculiaridades, nos cabendo aqui enfatizar a sua existência e atuação no âmbito da organização burocrática do esporte e do lazer materializada no aparato municipal.

Em que pese a preocupação e o esforço relativo à participação popular, foi relatada, pelos gestores dos municípios de Caxias do Sul e de Santa Maria, a realização de Conferências e Seminários Municipais de Esporte e Lazer. No caso de Caxias do Sul, essa realização está instituída pelo capítulo III da Lei 6076/2003 - aquela que cria a SMEL -, dispondo a Conferência Municipal de Esporte e de Lazer como instância de avaliação e de proposição das diretrizes da política municipal, convocada pelo secretário municipal a cada três $\operatorname{anos}^{25}$. No caso de Santa Maria, foi descrita a realização, durante vários anos, até 2008, de um Seminário Municipal de Esporte, que, segundo as gestoras entrevistadas, chegava a envolver mais de 500 pessoas, representando um case de sucesso da administração pública.

${ }^{20}$ CANOAS. Lei $\mathbf{n}^{\circ} \mathbf{4 . 6 8 2}$, de 18 de outubro de 2002. Altera a Lei ${ }^{\mathbf{o}} 3.145 / 91$, institui o Conselho Municipal do Esporte, Lazer e dá outras providências. Disponível em: http://c-mara-municipal-decanoas.jusbrasil.com.br/legislacao/321235/lei-4682-02 . Acesso em: Acesso em: 27 dez. 2012.

${ }^{21}$ CAXIAS DO SUL. Lei ${ }^{\circ} \mathbf{5 . 0 8 9}$, de 14 de abril de 1999. Cria o Conselho Municipal do Desporto (CMD) e dá outras providências. Disponível em: http://www.camaracaxias.rs.gov.br:81/web/legislacao.nsf/1f7775b92f2120a383256f380071f9ce/ab326f56f7b917 ab83256ee100476d67! OpenDocument . Acessado em: 28 dez. 2012.

${ }^{22}$ PORTO ALEGRE. Decreto $\mathbf{n}^{\mathbf{0}} \mathbf{1 5 . 1 2 6}$, de 15 março de 2006. Ratifica o regulamento do CMD que disciplina a participação dos beneficiários no PROESPORTE. Disponível em: http://www.camarapoa.rs.gov.br/biblioteca/integrais/Dec_15126.htm . Acesso em: 15 dez. 2012.

${ }^{23}$ SANTA MARIA. Lei $\mathbf{n}^{\circ} \mathbf{1 . 2 1 3}$, de 05 de novembro de 1965. Cria o Conselho Municipal de Desporto e dá outras providências. Disponível em: http://camara-municipal-da-santamaria.jusbrasil.com.br/legislacao/549033/lei-1213-65. Acesso em: 18 dez. 2012.

${ }^{24}$ SANTA MARIA. Lei ${ }^{\circ} 4.609$ de 17 de outubro de 2002. Altera a redação da Lei ${ }^{\circ} 1.213 / 65$, de 05-111965, que cria o Conselho Municipal de Desportos e dá outras providências. Disponível em: http://camaramunicipal-da-santa-maria.jusbrasil.com.br/legislacao/538830/lei-4609-02 . Acesso em: 18 dez. 2012.

${ }^{25}$ CAXIAS DO SUL. Lei $\mathbf{n}^{\circ} \mathbf{6 . 0 7 6}$, de 10 de setembro de 2003. Cria a Secretaria Municipal de Esporte e Lazer e dá outras providências. Disponível em: http://portal.tce.rs.gov.br/aplicprod/f?p=50202:4:263159601882518::NO::P4_CD_LEGISLACAO:190167 Acesso em: 28 dez. 2012 
A existência de Sistemas, Secretarias, Superintendências, Fundos, Conselhos, Conferências/Seminários dinamizava a execução das ações programáticas na área de esporte e de lazer, a maioria delas descritas na forma de programas e de projetos como formas organizacionais instituídas. Esses programas e projetos foram mencionados pelos gestores dos cinco municípios estudados, não ficando restritos a eventos, como Jogos Abertos, Escolares, Municipais, Campeonatos de modalidades, Atividades comemorativas de aniversário, de dia das mães, dos pais, estudantes, crianças, etc. Embora, nos relatos dos dirigentes, os eventos tivessem destaque na organização municipal, muitos outros programas e projetos foram mencionados, tais como: o Programa Atleta Cidadão do Futuro e o Programa Lazer, Atividade Física e Saúde, do município de Canoas; as Academias da Melhor Idade, o Projeto Talentos do Futuro, Caxias Navegar, Caxias Olímpico, Futuro Torcedor, Projeto Conviver, do município de Caxias do Sul; o Projeto de Taekwondo, de Xadrez, do município de Pelotas; o Programa Em Cada Campo uma Escolinha, o Programa Social Esporte Clube, o Projeto Graxaim, o Projeto Bonde da Cidadania, do município de Porto Alegre; o Programa de Atividades Esportivas para a Comunidade, o Projeto Judô de Mãos Dadas, o Projeto de Canoagem na Escola, do município de Santa Maria. Não listamos todos os programas/projetos que foram relatados pelos nossos interlocutores. Apenas trouxemos alguns exemplos, com o intuito de sustentar que eles caracterizam, de uma maneira substancial, a forma como a organização municipal se estrutura para objetivar administrativamente suas intervenções diretas.

Numa síntese analítica do que viemos descrevendo até aqui, podemos salientar que os municípios estudados procuraram conquistar, garantir e instituir legalmente uma estrutura burocrática (Sistemas Esportivos, Secretarias, Superintendências, Fundos, Conselhos, Conferências/Seminários, Programas e Projetos) para o esporte e o lazer. Além disso, nos ficou bastante evidente que a existência de uma estrutura organizacional específica expressava 
a maior capacidade de intervenção direta em ações relacionadas ao esporte e ao lazer, o que está vinculado ao tamanho e à autonomia do aparato burocrático (especificidade de cargos, funções, unidades, orçamentos, leis, decretos, resoluções, processos, hierarquias, etc.). Ao mesmo tempo em que essa estrutura burocrática institucionalizada confere impessoalidade, racionalidade legal-instrumental, até mesmo para dizer que se trata de uma política de Estado e não de governos, ela objetiva os meios materiais de existência do esporte e do lazer nas políticas de intervenção social, inclusive com a presença de arenas públicas de participação (Conselhos e Conferências/Seminários Municipais), estes elementos de uma configuração societal de gestão.

\section{Estrutura Administrativa de Captação e Repasse de Recursos}

Nas entrevistas com os interlocutores do estudo foi recorrente a manifestação de que a estrutura existente não era suficiente para o atendimento das demandas crescentes de esporte e de lazer. Uma dessas manifestações foi a do Gestor 05, ao tratar da organização administrativa, dos recursos e da gestão. Segundo ele,

[...] a questão do Esporte e Lazer, sob o ponto de vista de Políticas Públicas, vem criando uma demanda e ganhando espaço na gestão, porém, na outra ponta, não há um reconhecimento da importância disso sob o ponto de vista, realmente de fato, da Gestão Política; de recursos, recursos humanos, e tal [...] Eu acho - isso é muito pessoal né? - que há um descompasso ainda, entre a demanda e a necessidade, e a valorização no que diz respeito a esses aspectos (GESTOR 05).

Dentre os indicadores mais salientes dessa situação de descompasso estava a questão dos agentes responsáveis pela intervenção nas áreas de esporte e de lazer. Mostramos no Quadro 2 uma síntese das descrições dos servidores entrevistados, cujas informações ajudam a contextualizar um cenário de inexistência de concursos específicos para essas unidades/pastas, contando elas com funcionários cedidos por outros setores, como o exemplo dos professores cedidos pela Secretaria Municipal de Educação, no caso de Canoas, Pelotas e de Santa Maria. Alguns municípios contam com poucos funcionários concursados 
(estatutários), especialmente nos casos de Pelotas e Santa Maria. E, dentre aqueles que têm mais estatutários, Porto Alegre é o que mais reunia professores, mas, em anos anteriores, já contou com 120 deles e na época das entrevistas os gestores apontavam que eram apenas 90, havendo, portanto, um desinvestimento na estrutura direta. Além disso, tal cenário inclui o importante peso da atuação de monitores e de estagiários na intervenção.

Quadro 2 - Sínteses das descrições dos entrevistados no que se refere ao conjunto de pessoas atuantes nas unidades do esporte e do lazer.

\begin{tabular}{|c|c|}
\hline $\begin{array}{l}\text { Unidade de Esporte e Lazer, } \\
\text { Município }\end{array}$ & Síntese da descrição dos funcionários \\
\hline $\begin{array}{l}\text { Secretaria Municipal de Esporte e } \\
\text { Lazer } \\
\text { Canoas }\end{array}$ & $\begin{array}{l}\text { Os entrevistados descreveram que nessa Secretaria trabalham } 64 \text { pessoas, } \\
\text { dentre as quais nove relacionadas a questões administrativas, oito } \\
\text { professores-profissionais de Educação Física ou Esporte, nove } \\
\text { coordenadores de núcleos e } 38 \text { estagiários (estudantes de Educação Física } \\
\text { ou afins), estes dois últimos contratados pelo Centro de Integração } \\
\text { Empresa Escola (CIEE) ou pela Fundação La Salle. }\end{array}$ \\
\hline $\begin{array}{l}\text { Secretaria Municipal de Esporte e } \\
\text { Lazer } \\
\text { Caxias do Sul }\end{array}$ & $\begin{array}{l}\text { Os gestores que concederam as entrevistas mencionaram a existência de } \\
116 \text { pessoas trabalhando na Secretaria, dentre as quais professores } \\
\text { (formados em Educação Física), funcionários, monitores, estagiários e } \\
\text { terceirizados. }\end{array}$ \\
\hline $\begin{array}{l}\text { Superintendência de Desporto e } \\
\text { Lazer, Secretaria Municipal de } \\
\text { Educação e Desporto, } \\
\text { Pelotas }\end{array}$ & $\begin{array}{l}\text { Os dirigentes dessa Superintendência pontuaram que, para atender as } \\
\text { demandas, com exceção daquelas geridas pela Educação, a referida } \\
\text { Superintendência conta com oito pessoas no setor burocrático } \\
\text { administrativo, mais } 16 \text { agentes contratados para o PELC, cuja existência } \\
\text { ora persiste com recursos exclusivos da municipalidade (não mais do } \\
\text { Ministério do Esporte). }\end{array}$ \\
\hline $\begin{array}{l}\text { Secretaria Municipal de Esportes, } \\
\text { Recreação e Lazer } \\
\text { Porto Alegre }\end{array}$ & $\begin{array}{l}\text { Os dirigentes acusaram que o quadro de funcionários compreende } 90 \\
\text { professores de Educação Física, mas já foram enfáticos em lembrar que } \\
\text { esse número já chegou a } 120 \text {, diminuindo nos últimos anos. Além disso, } \\
\text { disseram que contam com } 50 \text { estagiários de Educação Física, além de } 25 \text { a } \\
45 \text { agentes do convênio com o Programa Esporte e Lazer da Cidade } \\
\text { (PELC) e alguns poucos operários especializados (marceneiro, serralheiro, } \\
\text { eletricista), cargos, segundo eles, em extinção, pois a tendência é a } \\
\text { terceirização. }\end{array}$ \\
\hline $\begin{array}{l}\text { Superintendência de Esportes e } \\
\text { Lazer, Secretaria de Juventude, } \\
\text { Esporte, Lazer, Idoso e Criança } \\
\text { Santa Maria }\end{array}$ & $\begin{array}{l}\text { Para desenvolver as atividades dessa unidade, os entrevistados informaram } \\
\text { que existem diversos profissionais, não sabendo precisar exatamente } \\
\text { quantos, mas que envolvem professores concursados (nenhum } \\
\text { especificamente para o esporte e o lazer), funcionários efetivos, } \\
\text { funcionários em cargos de comissão, além de acadêmicos de Educação } \\
\text { Física e áreas afins (estagiários). }\end{array}$ \\
\hline
\end{tabular}

Fonte: elaboração dos autores

Frente a um quadro de descompasso e de desinvestimento é que os entrevistados relataram a constituição de um conjunto de estruturas organizacionais que, embora sejam partes da administração pública, são mais flexíveis e destinadas a suportar as crescentes demandas de intervenções sem a ampliação do aparato burocrático existente ou ainda diante da diminuição deste. Trata-se, efetivamente, de um movimento gerencialista da administração 
pública, que sublinha a o financiamento e a regulação das ações em alternativa à intervenção direta, fortalecido pelo discurso da carência de recursos, da precariedade das condições existentes e dos limites da própria burocracia.

Nesta pesquisa, como indicadores mais salientes dessa atitude reformista, observamos dois movimentos organizacionais: um no sentido de captação de recursos; o outro no sentido de transferências de recursos.

\section{Organizações para Captação de Recursos}

A respeito do primeiro movimento notamos a constituição de uma organização municipal relativa ao esporte e ao lazer, desenvolvida em torno dos convênios com diferentes esferas de governos e também com a iniciativa privada. A partir das entrevistas com nossos interlocutores construímos a Figura 2 abaixo no sentido de ilustrar como os municípios estudados buscam captar recursos via projetos e editais para além do orçamento próprio.

Figura 2 - Esforços dos municípios na constituição de organizações de captação de recursos suplementares para atender as demandas relativas ao esporte e ao lazer.

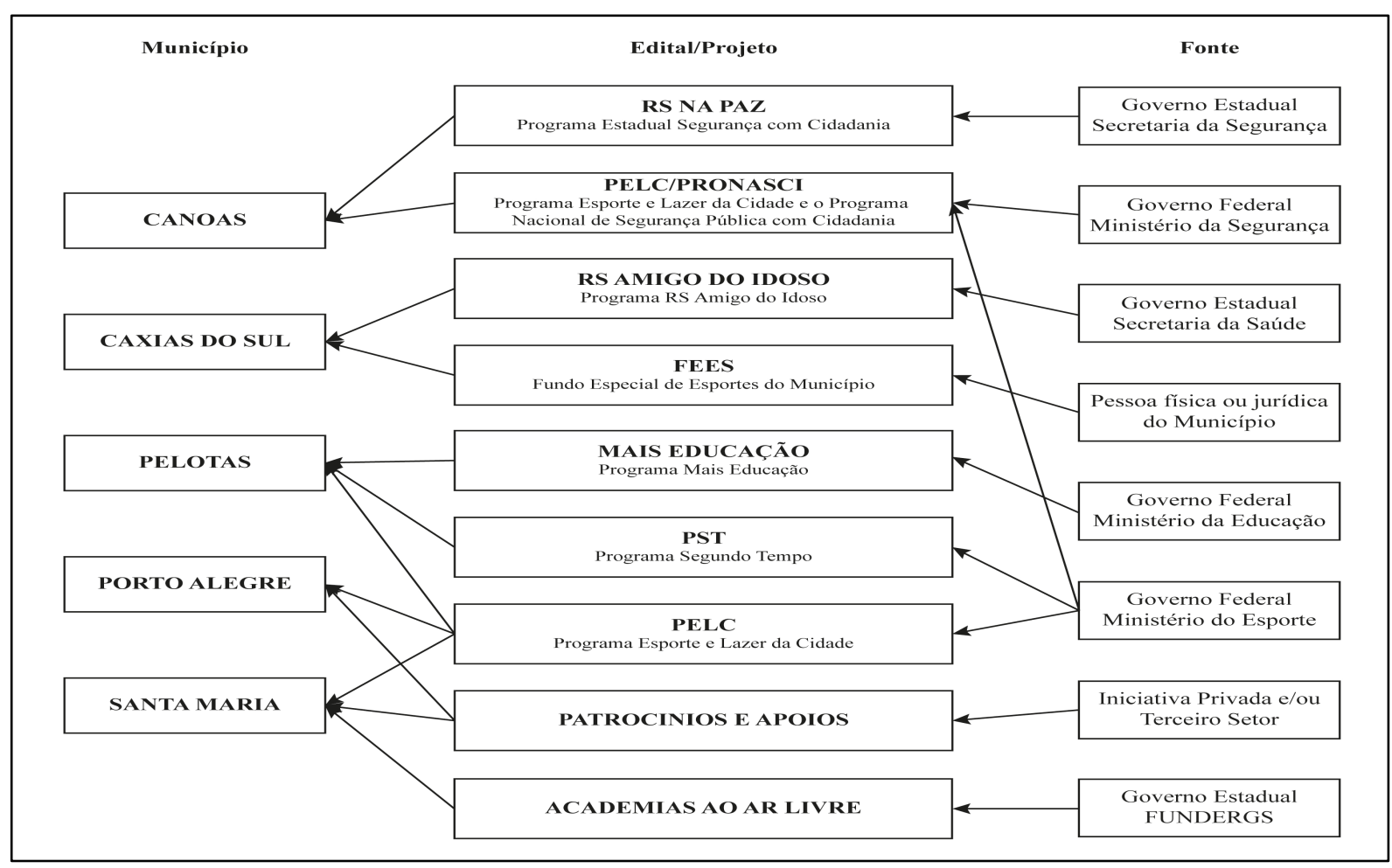

Fonte: elaboração dos autores 
Essa ilustração, construída a partir dos conteúdos das entrevistas, certamente não esgota a complexidade do fenômeno, mas mostra com clareza a existência de um esforço organizacional dos municípios em captar recursos suplementares para a construção de equipamentos públicos e contratação de pessoas para a intervenção na área de esporte e de lazer, com o propósito de ampliar a capacidade de ação. Disso deriva a relevância de contar com funcionários responsáveis pela captação, como salientaram os gestores entrevistados do município de Santa Maria, ao mencionarem a intencionalidade de contratar ou deslocar alguém exclusivamente para escrever e buscar recursos com outras instâncias, tanto públicas como da iniciativa privada.

Diante das dificuldades de ampliação da estrutura de intervenção própria, um dos desafios mencionados da organização baseada em projetos, editais e convênios trata da flexibilização, precariedade e descontinuidade das relações, especificamente no que se refere à contratação de pessoas para a intervenção (coordenadores, professores, estagiários, monitores). Nessas condições, enquanto o convênio do projeto está vigente, as condições concretas para sua implementação estão presentes, mas, quando o prazo se esgota, nem sempre é possível ou mesmo desejável a renovação e a continuidade.

Numa situação como essa é que os legisladores do município de Pelotas, após o término do convênio do Programa Esporte e Lazer da Cidade (PELC) com o Ministério do Esporte, aprovaram a Lei 5789/2011 26 , autorizando o Poder Executivo a contratar servidores para atuar no Programa, porém, por tempo determinado e na forma de contrato administrativo, visando atender necessidade temporária, pelo período de um ano, o que denota um esforço de ampliação da capacidade de garantia do esporte e do lazer como direitos sociais, mas isso baseado em relações transitórias. Isso alimenta uma política de indução dos municípios para que estes implementem ações de proteção social alinhadas aos Governos do Estado e da

${ }^{26}$ PELOTAS. Lei $\mathbf{n}^{\circ} \mathbf{5 . 7 8 9}$, de 25 de abril de 2011. Autoriza o Poder Executivo a contratar servidores para atuarem no Programa Esporte e Lazer da Cidade-PELC. Disponível em: http://www.pelotas.rs.gov.br/interesse_legislacao/leis/2011/lei_5789.pdf. Acesso em: 30 dez. 2012. 
União, mas em condições precárias no que diz respeito à continuidade dos investimentos e das relações.

Além disso, o peso das contrapartidas exigidas nos programas/editais também aparece como um desafio ou um obstáculo. Tal aspecto fez com que o município de Caxias do Sul, por exemplo, conforme o gestor entrevistado, raramente efetivasse convênios com os Governos do Estado ou da União. Segundo o gestor desse município, “[...] foi colocado 'na ponta do lápis' e se percebeu que os valores investidos na contrapartida superavam os que seriam gastos pelo município com uma execução administrada exclusivamente por ele". É exatamente este município que, com o propósito de captar recursos adicionais, cria um Fundo Especial de Esportes do Município (o FEES) cuja existência tem por finalidade a captação da receita auferida com tarifas cobradas pela utilização dos espaços públicos de esporte e lazer e custeio de despesas, encargos ou investimentos. Também constituem recursos do FEES receitas auferidas com doações e repasses, públicos ou particulares, subvenções, auxílios e mais aquelas obtidas por contratos de exploração de espaços públicos, autorizados legalmente ${ }^{27,28}$.

Esse exemplo do FEES coloca em evidência o que estamos chamando de uma engenharia organizacional orientada para a captação de recursos adicionais ao orçamento municipal e que envolve outras ações, conforme ilustra a Figura 2. Nessa mesma direção é que ganha sentido a proposta de comercialização de eventos mencionada por um dos gestores da Secretaria Municipal de Esporte, Lazer e Recreação (SME) de Porto Alegre. Segundo ele, são desenvolvidos, pela própria Secretaria, projetos comerciais que apresentam as necessidades dos eventos e buscam parceiros apoiadores para tais finalidades. Nesse ponto o

\footnotetext{
${ }^{27}$ CAXIAS DO SUL. Lei $\mathbf{n}^{\mathbf{0}} \mathbf{6 . 1 6 0}$, de 17 de novembro de 2003. Cria o Fundo Municipal de Desenvolvimento do Esporte e Lazer de Caxias do Sul (FUNDEL) e o Fundo Especial de Esportes do Município (FEES). Disponível em: http://www.camaracaxias.rs.gov.br/Leis/LO/LO-06160.pdf . Acesso em: 06 jan. 2013.

${ }^{28}$ CAXIAS DO SUL. Lei $\mathbf{n}^{\mathbf{0}} \mathbf{7 . 2 0 7}$, de 10 de novembro de 2010. Reformula o Fundo Municipal de Desenvolvimento do Esporte e Lazer de Caxias do Sul (FUNDEL) e do Fundo Especial de Esportes do Município (FEES). Disponível em: http://www.camaracaxias.rs.gov.br/Leis/LO/LO-07207.pdf . Acesso em: 06 jan. 2013.
} 
Gerente mencionou que a SME havia confeccionado um documento que estava sendo encaminhado para o jurídico, e esse documento, basicamente, dava publicidade aos projetos comerciais que a secretaria desenvolvia. Dessa maneira, a empresa que tivesse interesse em apoiar algum evento estaria amparada legalmente, bem como o município, pois a oferta foi tornada pública.

O que essas informações nos mostram é que, por um lado, a engenharia organizacional de captação de recursos adicionais se aproxima de uma lógica de prestação de serviços (como ocorre com a proposta de projetos comerciais e da cobrança de tarifas) e, por outro, de uma gestão de uma institucionalização flexível no sentido de que estão baseadas em editais e convênios que, ao descentralizarem, transferem as responsabilidades para os destinatários dos recursos (os municípios, nesse caso) sem lhes garantir maiores ou melhores possibilidades concretas de continuidade institucional.

\section{Organizações de Indução e Transferências de Recursos}

O segundo movimento que identificamos nas manifestações dos gestores, este direcionado à ampliação da capacidade de intervenção em condições de dificuldades quanto à existência de estrutura (não apenas ao orçamento) ou mesmo para escapar das 'amarras da burocracia', está relacionado a engenharias de parcerias, apoios e de incentivos fiscais. Levando em consideração os conteúdos das entrevistas, também desenvolvemos uma ilustração (Figura 3) sobre como os municípios investigados têm constituído essas parcerias, apoios e incentivos para subsidiar as suas ações ou subvencionar outras entidades/organizações em troca de contrapartidas. 
Figura 3 - Esforços dos municípios para subsidiar suas ações programáticas ou subvencionar ações de outras entidades na área de esporte e de lazer.

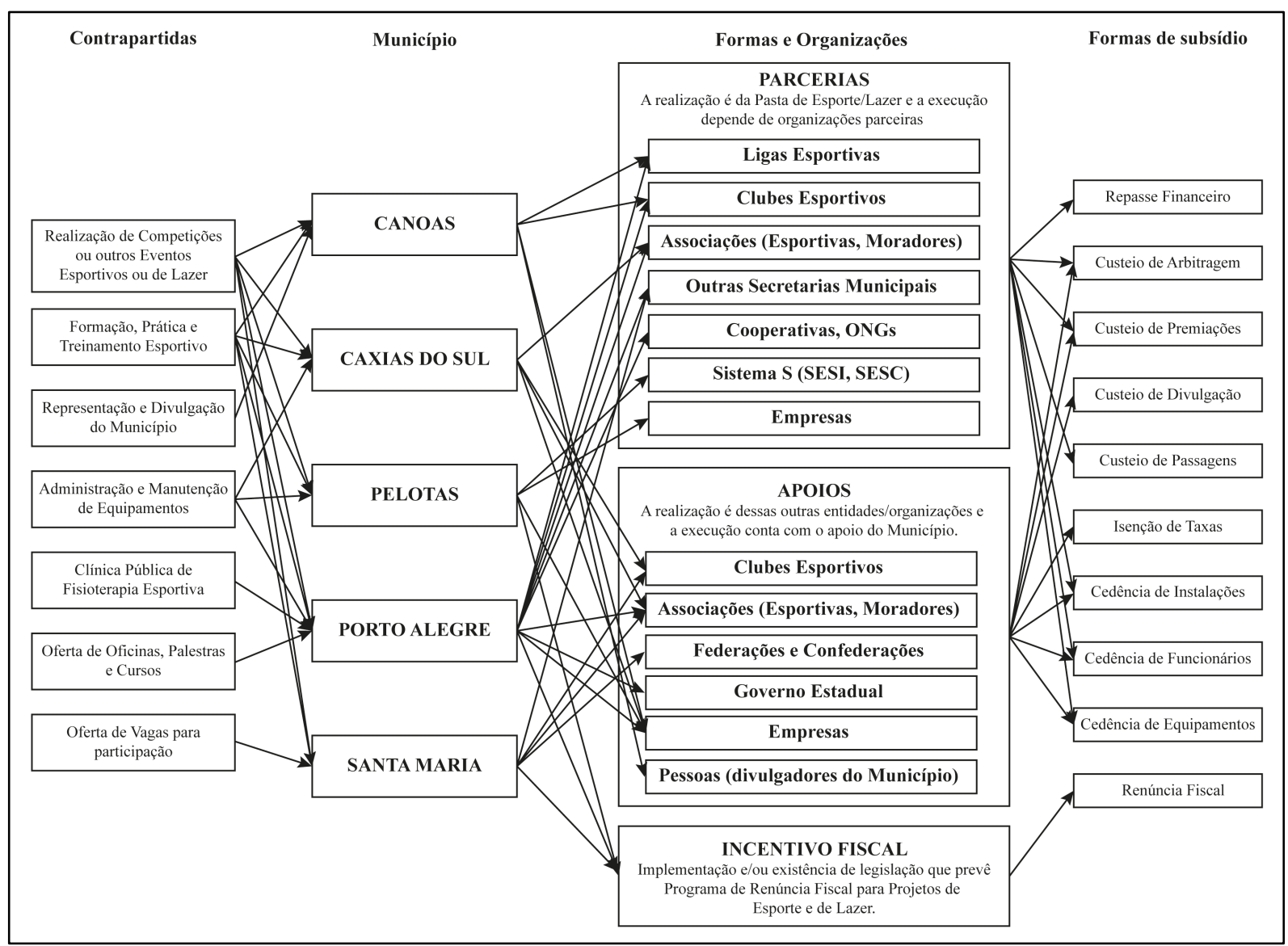

Fonte: elaboração dos autores.

Esta Figura mostra uma questão bastante enfatizada nas entrevistas. Diante da necessidade de contrapartidas (com ênfase na realização de eventos e competições e na oferta de treinamento, formação e oportunidades de prática esportiva), o município busca parceiros para a execução de suas ações programáticas ou estabelece formas de apoio para outras organizações desenvolverem suas ações. Também nessa linha de descentralização da execução se observa a estratégia de incentivo fiscal, mediante programas de renúncia em favor daquelas entidades sem fins lucrativos que realizam ações na área de esporte e de lazer. Resultam dessas estratégias organizacionais diferentes tipos de subsídios, dentre os quais, nos conteúdos das entrevistas, foram descritos os seguintes: repasse financeiro; custeio de arbitragem, de divulgação, de premiações, de passagens; isenção de taxas; cedência de instalações, de funcionários, de equipamentos; renúncia fiscal. 
No caso das parcerias, um dos exemplos mencionados que é ilustrativo porque diz sobre a necessidade de 'facilitação', se refere àquela estabelecida entre a Superintendência de Esporte e de Lazer do Município de Pelotas com instituições do Sistema S (SESI e SESC). Nesse sentido, numa de suas explicações, o gestor entrevistado deste município explica que:

Fazer as coisas com sistema "S" é mais tranquilo. Nós temos os Jogos da Rede Municipal de Ensino. Eu faço o JEPEL, os Jogos Escolares de Pelotas, que esse ano foi com característica de Olimpíada, e fizemos com eles [o SESI], porque facilita para a gente muita coisa, eles já têm tudo licitado, juízes, enfim. Então, foi muito mais fácil e ágil de fazer o processo.

Além dessa necessidade de 'facilitação', as parcerias também eram feitas no sentido de ampliação da capacidade estrutural de garantia do direito social ao esporte e ao lazer. Os dirigentes da Secretaria Municipal de Esportes, Lazer e Recreação de Porto Alegre, por exemplo, para a execução do Programa Social Esporte Clube, mencionaram o desenvolvimento de convênios com Clubes (Sociedade Ginástica de Porto Alegre, Grêmio Náutico União, São José, Associação Cristã de Moços, Caixeiros Viajantes, Grêmio Náutico Gaúcho, Gondoleiros, Hípica, Lindóia Tênis Clube, Planet Ball, Teresópolis Tênis Clube, Camisa 10, Geraldo Santana e Escolinha de Futebol da Duda), os quais possibilitavam a participação de crianças na prática de várias modalidades. Outro convênio da Secretaria de Porto Alegre, considerado de grande relevância, foi feito com o Hospital Mãe de Deus, para a implementação da Clínica Pública de Fisioterapia Esportiva.

Mas, como retrata o esquema da Figura 3, além das parcerias existem as configurações de apoios, como o que foi efetivado pela Secretaria Municipal de Esporte e Lazer de Canoas, pagando, no ano de 2012, os custos de arbitragem de partidas de futebol de campo, de areia e society, para as Ligas Municipais cadastradas. Nesse caso, a execução era das Ligas, mas a Secretaria apoiava financeiramente o custeio de despesas essenciais para a realização das competições. Outra dessas estratégias organizacionais foi relatada pelos dirigentes da Superintendência de Esporte e de Lazer do Município de Santa Maria. Segundo eles, nos 
últimos quatro anos foram realizadas diversas ações através de convênios, onde foram repassados recursos financeiros para entidades que os aplicaram nos eventos, fazendo prestação de contas da aplicação da verba recebida. Entre estas, as responsáveis pela gestão do esporte e lazer referem destaque aos convênios com clubes de futebol, com federações gaúchas de diferentes modalidades esportivas, com a Associação Gaúcha de Cavalo de Rédeas e com confederações brasileiras de diferentes modalidades esportivas.

Uma preocupação central dos dirigentes quanto a essas configurações organizacionais (parcerias e apoios) estava flagrantemente relacionada à legalidade e racionalidade dos procedimentos. No caso da Secretaria Municipal de Esporte e Lazer de Canoas, tal preocupação levou o secretário entrevistado a explicar que os recursos "foram disponibilizados para instituições que apresentam algum tipo de projeto, mas, por não existir um modelo previamente instituído, esse projeto é avaliado pela SMEL e pelo prefeito, e, conforme o caso, passa pelo Conselho Municipal de Esporte e Lazer [...]”. Segundo este dirigente, essa disponibilização de recursos financeiros estava prevista na Lei 3756/1993 ${ }^{29}$, regulamentada pelo Decreto $623 / 1997^{30}$, o município pode distribuir auxílio para as entidades esportivas locais.

Somada às parcerias e aos apoios, ainda verificamos a estratégia organizacional de subvencionamento baseada em incentivos fiscais, isto é, uma renúncia de pagamento de impostos municipais em favor daqueles que direcionam recursos financeiros para ações ou projetos na área de esporte. Tal modo de subvencionamento foi relatado pelos entrevistados vinculados à SME de Porto Alegre e à Superintendência de Esporte e Lazer de Santa Maria. No caso de Porto Alegre, foi mencionada a existência do Programa Municipal de Apoio e

\footnotetext{
${ }^{29}$ CANOAS. Lei $\mathbf{n}^{\circ}$ 3.756, de 17 de setembro de 1993. Dá normas sobre a distribuição de auxílio às Entidades Esportivas do Município. Disponível em: http://c-mara-municipal-decanoas.jusbrasil.com.br/legislacao/326475/lei-3756-93. Acesso em: 27 dez. 2012.

${ }^{30}$ CANOAS. Decreto $\mathbf{n}^{\mathbf{0}}$ 623, de 24 de setembro de 1997. Regulamenta a Lei $\mathrm{n}^{\mathbf{0}} 3.756$, de 17 de setembro de 1993, que dispõe sobre a distribuição de auxílio às entidades esportivas do Município e revoga os decretos. Disponível em: http://c-mara-municipal-de-canoas.jusbrasil.com.br/legislacao/921284/decreto-623-97 . Acesso em: 27 dez. 2012.
} 
Promoção do Esporte (PROESPORTE), criado pela Lei 530/2005, que possibilitava a realização de projetos ligados ao esporte, autorizando a participação de pessoas jurídicas e físicas que tivessem interesse e que não figurassem como inadimplentes, concedendo o direito a abater $70 \%$ desse investimento nos tributos de Imposto Predial Territorial Urbano (IPTU) ou de Imposto sobre Serviço de Qualquer Natureza (ISSQN) ${ }^{31}$. No que se refere a Santa Maria, foi mencionado o Programa Municipal de Apoio e Promoção do Esporte (PROESP), criado pela Lei 5157/2008, regulamentado pelo Decreto executivo 142/2008, permitindo às entidades com regularidade fiscal captarem valores de uma renúncia fiscal, limitados ao Imposto sobre Serviço de Qualquer Natureza (ISSQN), ao Imposto Predial Territorial Urbano (IPTU) e ao Imposto de transmissão Inter Vivos de Bens Imóveis (ITVBI) ${ }^{32}$.

Tais informações sobre a existência de programas de incentivo fiscal, assim como da realização frequente de parcerias e apoios, indicam um esforço para suplantar as dificuldades advindas do descompasso que mencionamos (crescente demanda e desinvestimento na estrutura organizacional) em que pese a garantia, pelos municípios, do esporte e do lazer como direitos sociais. Nesse contexto, as parcerias, os apoios e os incentivos fiscais configuram engenharias organizacionais, mais flexíveis e com prazos delimitados, que 'facilitavam' a transferência de recursos e que eram eficientes na indução de ações por outras entidades, numa espécie de descentralização necessária para dar conta das demandas. E, em entrevistas com os gestores dos municípios de Canoas, Porto Alegre e Santa Maria, estes mencionaram o envolvimento dos Conselhos Municipais - aqueles órgãos que caracterizavam arenas de participação pública, popular - nas análises, legitimação e até mesmo fiscalização dos convênios, operando, portanto, numa lógica gerencialista.

\footnotetext{
${ }^{31}$ PORTO ALEGRE. Lei $\mathbf{n}^{\circ} \mathbf{5 3 0}$, de 22 de dezembro de 2005. Institui o Programa Municipal de Apoio e Promoção do Esporte - $\quad$ PROESPORTE [...]. http://www.camarapoa.rs.gov.br/biblioteca/integrais/LC530AtualizadoatéLC579.htm . Acesso em: 30 dez. 2012. 32 SANTA MARIA. Decreto executivo $n^{\mathbf{0}}$ 142, de 01 de dezembro de 2008. Regulamenta o Programa Municipal de Apoio e Promoção do Esporte - PROESP-SM, instituído pela Lei Municipal $n^{\circ} 5157$, de 03 de outubro de 2008. Disponível em: https://www.santamaria.rs.gov.br/docs/2008/doc_20081201_05040806-37.pdf. Acesso em: 30 dez. 2012.
} 


\section{Considerações Finais}

Iniciamos este trabalho contextualizando a questão da municipalização das ações de Estado, como um redesenho da estrutura organizacional do sistema de proteção social brasileiro. Destacamos que essa é também uma preocupação no campo do esporte e do lazer enquanto direitos sociais do cidadão brasileiro, aspecto que nos levou a investigar as configurações organizacionais materializadas nos esforços administrativos dos cinco municípios mais populosos do Rio Grande do Sul (Porto Alegre, Caxias do Sul, Pelotas, Canoas e Santa Maria), entre os anos de 2009 e 2012. Após apresentarmos aspectos sobre nossas decisões metodológicas, como também trazermos descrições analíticas sobre o que chamamos de configurações organizacionais, temos condições de apresentar algumas conclusões a respeito da gestão pública do esporte e do lazer nos municípios estudados.

A primeira conclusão foi a de que os esforços materializados nas configurações organizacionais denotam um modelo híbrido de gestão pública do esporte e do lazer, englobando - de maneira sobreposta e inter-relacionada - estruturas relacionadas a dimensões da administração burocrática, da reforma gerencialista e da vertente societal. Observamos o anseio pela conquista e institucionalização de uma maior estrutura no aparato burocrático municipal, o que equivale a um reconhecimento do esporte e do lazer enquanto questões de relevância social. Simultaneamente notamos a existência e o funcionamento de configurações organizacionais que materializavam arenas públicas de participação (destaque para os Conselhos Municipais), assim como o desejo de constituição de agências executivas descentralizadas, como as Fundações Municipais.

Numa síntese mais geral das análises, podemos afirmar que os esforços administrativos relatados pelos gestores entrevistados e constantes nos conteúdos dos documentos contemplam duas direções: uma primeira que se refere à constituição ou ampliação de estrutura organizacional de intervenção direta, esta bastante vinculada com a 
noção de burocracia num sentido de instituição da existência e da autonomia do esporte e do lazer no aparato de gestão municipal; e uma segunda, relacionada ao enfrentamento do crescimento da demanda pelo esporte e lazer sem crescimento correspondente na estrutura burocrático-administrativa municipal (ou até mesmo desinvestimento - um descompasso), do que deriva o desenvolvimento de engenharias organizacionais de 'captação' e de 'transferência' de recursos, estas, em contraponto à rigidez burocrática, de caráter flexível, dinâmico e contingente. Esta segunda direção trata de uma gestão pública de financiamento e regulação, baseada em editais e/ou convênios, tanto no que diz respeito à conquista de condições concretas precárias para a ação social direta, como para a efetivação de ações de descentralizações que motivam um conjunto diverso de parcerias e de apoios, assim como a existência de programas de incentivo fiscal.

Tais direções dos esforços materializados nas configurações e o hibridismo organizacional ajudam a mostrar um cenário de valorização da formação e da atuação tecnocrática, fazendo com que a existência do esporte e do lazer no aparato do executivo municipal esteja também (e substancialmente) sustentada em modelos organizacionais de contingência, puxados pelas demandas de governos e dos grupos/entidades de prática esportiva e de lazer.

\section{REFERÊNCIAS}

AMARAL, Sílvia Cristina Franco; COSTA, Eduardo Tadeu. Possibilidades de matricialidade na administração pública do lazer. Movimento, Porto Alegre, v. 18, n. 01, p. 205-220, $\mathrm{jan} / \mathrm{mar}$ de 2012.

; KIKUCHI, Deise Miki. Política Pública de Lazer em Suzano/SP: a concepção dos gestores. Licere, Belo Horizonte, v.14, n.1, mar., 2011.

ARRETCHE, M. T. S. Políticas sociais no Brasil: descentralização em um Estado federativo. Revista Brasileira de Ciências Sociais, v. 14, n. 40, p. 111-141, 1999. 
BOURDIEU, Pierre. Da casa do rei à razão de Estado: um modelo da gênese do campo burocrático. In: WACQUANT, Löic (Org.). O mistério do ministério: Pierre Bourdieu e a política democrática. Rio de Janeiro: Revan, 2005. p. 41-70.

BRASIL. Constituição Federal. Constituição da República Federativa do Brasil. Brasília: Senado Federal, $1988 . \quad$ Disponível em: http://www.planalto.gov.br/ccivil_03/constituicao/constituicao.htm Acesso em: 13 jan. 2013.

Ministério do Esporte. Documento final da II Conferência Nacional do Esporte.

Ministério do Esporte. Brasília: 2006. Disponível em:
http://portal.esporte.gov.br/conferencianacional/conferencia2/documentoFinal.jsp Acesso em: 13 jan. 2013.

BRESSER-PEREIRA, Luiz Carlos. A reforma gerencial do Estado de 1995. Revista de Administração Pública, Rio de Janeiro, v. 34, n. 4, jul./ago., p. 55-72, 2000.

Da administração pública burocrática à gerencial. Revista do Serviço Público, Brasília, v. 47, n. 1, jan./abr.,1996.

CANOAS. Lei $\mathbf{n}^{0}$ 5.363, de 02 de janeiro de 2009. Dispõe sobre a estrutura, organização e funcionamento do poder executivo municipal de Canoas e dá outras providências. Disponível em: http:/c-mara-municipal-de-canoas.jusbrasil.com.br/legislacao/311168/lei-5363-09 Acesso em: 27 dez. 2012.

Lei $n^{\circ}$ 4.682, de 18 de outubro de 2002. Altera a Lei $n^{\circ} 3.145 / 91$, institui o Conselho Municipal do Esporte, Lazer e dá outras providências. Disponível em: http://c-maramunicipal-de-canoas.jusbrasil.com.br/legislacao/321235/lei-4682-02 Acesso em: Acesso em: 27 dez. 2012.

Lei n $^{\circ}$ 3.756, de 17 de setembro de 1993. Dá normas sobre a distribuição de auxílio às Entidades Esportivas do Município. Disponível em: http://c-mara-municipal-decanoas.jusbrasil.com.br/legislacao/326475/lei-3756-93. Acesso em: 27 dez. 2012.

Decreto $\mathbf{n}^{0}$ 623, de 24 de setembro de 1997. Regulamenta a Lei no 3.756, de 17 de setembro de 1993, que dispõe sobre a distribuição de auxílio às entidades esportivas do Município e revoga os decretos. Disponível em: http://c-mara-municipal-decanoas.jusbrasil.com.br/legislacao/921284/decreto-623-97. Acesso em: 27 dez. 2012.

CASTELLANI FILHO, Lino. Gestão municipal e política de lazer. In: ISAYAMA, Hélder Ferreira; LINHALES, Meily Assbú (Org.). Sobre lazer e política: maneiras de ver, maneiras de fazer. Belo Horizonte: UFMG, 2006.

O projeto social Esporte e Lazer da Cidade: da elaboração conceitual à sua implementação. In: CASTELLANI FILHO, Lino. (Org.). Gestão pública e política de lazer: a formação de agentes sociais. Campinas: Autores Associados, 2007.

CAXIAS DO SUL. Lei $\mathbf{n}^{\circ} \mathbf{6 . 0 7 6}$, de 10 de setembro de 2003. Cria a Secretaria Municipal de Esporte e Lazer e dá outras providências. Disponível em: http://portal.tce.rs.gov.br/aplicprod/f?p=50202:4:263159601882518::NO::P4 CD LEGISLA CAO:190167 . Acesso em: 28 dez. 2012. 
CAXIAS DO SUL. Lei complementar $\mathbf{n}^{\circ}$ 321, de 22 de dezembro de 2008. Dispõe sobre a estrutura administrativa e o funcionamento do Poder Executivo Municipal de Caxias do Sul. Disponível em: http://hamurabi.camaracaxias.rs.gov.br/Hamurabifaces/externo/exibicao.jsf?leiId=1322\&from=resultados Acesso em: $28 \mathrm{dez} .2012$.

Lei $\mathrm{n}^{0}$ 6.160, de 17 de novembro de 2003. Cria o Fundo Municipal de Desenvolvimento do Esporte e Lazer de Caxias do Sul (FUNDEL) e o Fundo Especial de Esportes do Município (FEES). Disponível em: http://www.camaracaxias.rs.gov.br/Leis/LO/LO-06160.pdf . Acesso em: 06 jan. 2013.

Lei $n^{0}$ 7.207, de 10 de novembro de 2010. Reformula o Fundo Municipal de Desenvolvimento do Esporte e Lazer de Caxias do Sul (FUNDEL) e do Fundo Especial de Esportes do Município (FEES). Disponível em: http://www.camaracaxias.rs.gov.br/Leis/LO/LO-07207.pdf . Acesso em: 06 jan. 2013.

. Lei $n^{\circ}$ 5.089, de 14 de abril de 1999. Cria o Conselho Municipal do Desporto $\overline{(C M D)}$ e dá outras providências. Disponível em: http://www.camaracaxias.rs.gov.br:81/web/legislacao.nsf/1f7775b92f2120a383256f380071f9 ce/ab326f56f7b917ab83256ee100476d67! OpenDocument Acesso em: 28 dez. 2012.

FLICK, Uwe. Uma introdução à pesquisa qualitativa. 2. ed. Porto Alegre: Bookman, 2007.

LINHALES, Meily Assbú; LOPES, Tarcila Bretas; COSTA, Luciana Cirino Lages Rodrigues; LIMA, Cássia Danielle Monteiro Dias; PEREIRA, Thiago Marques. Esporte e lazer na Grande-BH: por onde caminham as gestões públicas? In: ISAYAMA, Hélder Ferreira: LINHALES, Meily Assbú (Org.). Avaliação de Políticas e Políticas de Avaliação: questões para o esporte e o lazer. Belo Horizonte: UFMG, 2008.

MENEZES, Vilde Gomes; OLIVEIRA, Aurenéa Maria; SOUZA, Edílson Fernandes. Gestão desportiva e política pública na região metropolitana de Recife. Revista Brasileira de Educação Física e Esporte, São Paulo, v.26, n.2, p.219-30, abr./jun., 2012.

PAULA, Ana Paula Paes. Por uma nova gestão pública: limites e potencialidades da experiência contemporânea. Rio de Janeiro: Editora FGV, 2005.

PELOTAS. Lei $\mathbf{n}^{\circ}$ 5.789, de 25 de abril de 2011. Autoriza o Poder Executivo a contratar servidores para atuarem no Programa Esporte e Lazer da Cidade-PELC. Disponível em: http://www.pelotas.rs.gov.br/interesse legislacao/leis/2011/lei 5789.pdf Acesso em: 30 dez. 2012.

Lei $\mathrm{n}^{\circ}$ 5.763, de 23 de dezembro de 2010. Dispõe sobre a Reforma Administrativa do Poder Executivo do Município de Pelotas, consolida a Legislação acerca dos Cargos em Comissão e das Funções Gratificadas. Disponível em: http://externo.pelotas.com.br:51000/transparencia/leis-e-decretos/leis.php?secao=listaLEIS.htm?tipo site=1 Acesso em: 29 dez. 2012. 
PELOTAS. Lei $\mathbf{n}^{\mathbf{0}} \mathbf{3 . 4 8 4}$, de 12 de fevereiro de 1992. Dispõe sobre a Fundação de Cultura, Esporte, Lazer e Turismo de Pelotas e dá outras providências. Disponível em: https://www.leismunicipais.com.br/a/rs/p/pelotas/lei-ordinaria/1992/348/3484/lei-ordinaria-n3484-1992-dispoe-sobre-a-fundacao-de-cultura-esporte-lazer-e-turismo-de-pelotas-e-daoutras-providencias.html Acesso em: 30 dez. 2012.

PORTO ALEGRE. Decreto $\mathbf{n}^{\mathbf{0}}$ 15.126, de 15 março de 2006. Ratifica o regulamento do CMD que disciplina a participação dos beneficiários no PROESPORTE. Disponível em: http://www.camarapoa.rs.gov.br/biblioteca/integrais/Dec 15126.htm Acesso em: 15 dez. 2012.

Lei Complementar no 340, de 12 de janeiro de 1995. Institui o Sistema Municipal do Desporto e dá outras providências. Disponível em: http://www2.portoalegre.rs.gov.br/sme/default.php?reg=5\&p secao=99. Acesso em: 29 dez. 2012.

Lei ${ }^{\circ}$ 7330, de 05 de outubro de 1993. Cria a Secretaria Municipal de Esportes, Recreação e Lazer - SME, e dá outras providências. Disponível em: http://www2.portoalegre.rs.gov.br/netahtml/sirel/avancada.html Acesso em: 28 dez. 2012.

Lei Complementar no 340, de 12 de janeiro de 1995. Institui o Sistema Municipal do Desporto e dá outras providências. Disponível em: http://www2.portoalegre.rs.gov.br/sme/default.php?reg=5\&p secao=99 Acesso em: 29 dez. 2012.

Decreto $\mathrm{N}^{0}$ 11.481, de 15 de abril de 1996. Regulamenta a Lei Complementar $\mathrm{n}^{\circ}$ 340, de 12 de janeiro de 1995, que institui o Sistema Municipal de Desporto. Disponível em: http://www2.portoalegre.rs.gov.br/sme/default.php?reg=6\&p_secao=99 Acesso em: 29 dez. 2012.

Lei $\mathbf{n}^{\circ}$ 530, de 22 de dezembro de 2005. Institui o Programa Municipal de Apoio e Promoção do Esporte - PROESPORTE [...]. Disponível em: http://www.camarapoa.rs.gov.br/biblioteca/integrais/LC530AtualizadoatéLC579.htm Acesso em: 30 dez. 2012.

RODRIGUES, Rejane Penna; MARCELLINO, Nelson Carvalho. O lazer nas Políticas Públicas Participativas de Porto Alegre: estudo das gestões municipais de 1994-2004. Licere, Belo Horizonte, v.14, n.3, set., 2011.

SANTA MARIA. Lei $\mathbf{n}^{\mathbf{0}}$ 5.189, de 30 de abril de 2009. Dispõe sobre a estrutura, organização e funcionamento do poder executivo municipal, altera a Lei 4821, de 18 de janeiro de 2005, e dá outras providências. Disponível em: http://www.leismunicipais.com.br/legislacaomunicipal-da-prefeitura/4210/leis-de-santa-maria.html Acesso em: 30 dez. 2012.

Lei $n^{\circ} 1.213$, de 05 de novembro de 1965. Cria o Conselho Municipal de Desporto e dá outras providências. Disponível em: http://camara-municipal-da-santamaria.jusbrasil.com.br/legislacao/549033/lei-1213-65 Acesso em: 18 dez. 2012. 
SANTA MARIA. Lei $n^{\circ} 4.609$ de 17 de outubro de 2002. Altera a redação da Lei $n^{\circ}$ 1.213/65, de 05-11-1965, que cria o Conselho Municipal de Desportos e dá outras providências. Disponível em: http://camara-municipal-da-santamaria.jusbrasil.com.br/legislacao/538830/lei-4609-02. Acesso em: 18 dez. 2012.

SANTA MARIA. Decreto executivo $\mathbf{n}^{\mathbf{0}}$ 142, de 01 de dezembro de 2008. Regulamenta o Programa Municipal de Apoio e Promoção do Esporte - PROESP-SM, instituído pela Lei Municipal $\mathrm{n}^{\mathrm{o}}$ 5157, de 03 de outubro de 2008. Disponível em: https://www.santamaria.rs.gov.br/docs/2008/doc 20081201 05040806-37.pdf . Acesso em: 30 dez. 2012.

SAWITZKI, Rosalvo Luis. Políticas Públicas para Esporte e Lazer: para além do calendário de eventos esportivos. Licere, Belo Horizonte, v.15, n.1, mar., 2012.

SILVA, Dirceu Santos; AVILA, Marco Aurélio; SANTOS, Marcel Ivan dos; BORGES, Carlos Nazareno Ferreira. Ações intersetoriais no planejamento político em esporte, lazer, cultura e turismo na gestão municipal de Ilhéus-BA. Belo Horizonte, Licere, v. 15, n. 1, mar., 2012.

STIGGER, M. P. Administração de Parques Públicos e Democracia: um estudo de caso na área de políticas públicas para um lazer na perspectiva democrática. $1992.153 \mathrm{f}$. Dissertação (Mestrado) - Programa de Pós-Graduação em Educação Física, Universidade Gama Filho, Rio de Janeiro, 1992.

WEBER, Max. Economia e sociedade: fundamentos da sociologia compreensiva. 4. ed. Brasília: Universidade de Brasília, 2009.

\section{Endereço dos Autores:}

Filipe Fuhrmann Mertins

Rua Alfredo Marotzki, 657, bairro Canudos

Novo Hamburgo - RS - 93.540-200

Endereço Eletrônico: mertinsbr@gmail.com

Mauro Myskiw

Rua Felizardo, 750, Jardim Botânico

Porto Alegre - RS - 90.690-200

Endereço Eletrônico: mmyskiw@hotmail.com

Gustavo Roese Sanfelice

Rua Carlos Gomes, 231, apto 1002

Novo Hamburgo - RS - 93.315-040

Endereço Eletrônico: sanfeliceg@hotmail.com 